\title{
Disrupting Climate Change Futures Conceptual Tools for Lost Histories
}

\author{
De Cock, Christian ; Nyberg, Daniel; Wright, Christopher
}

Document Version

Accepted author manuscript

Published in:

Organization

DOI:

$10.1177 / 1350508419883377$

Publication date:

2021

License

Unspecified

Citation for published version (APA):

De Cock, C., Nyberg, D., \& Wright, C. (2021). Disrupting Climate Change Futures: Conceptual Tools for Lost Histories. Organization, 28(3), 468-482. https://doi.org/10.1177/1350508419883377

Link to publication in CBS Research Portal

\section{General rights}

Copyright and moral rights for the publications made accessible in the public portal are retained by the authors and/or other copyright owners and it is a condition of accessing publications that users recognise and abide by the legal requirements associated with these rights.

Take down policy

If you believe that this document breaches copyright please contact us (research.lib@cbs.dk) providing details, and we will remove access to the work immediately and investigate your claim. 


\title{
Disrupting Climate Change Futures: Conceptual Tools for Lost Histories
}

\author{
Christian De Cock, Daniel Nyberg, and Christopher Wright
}

Journal article (Accepted manuscript*)

Please cite this article as:

De Cock, C., Nyberg, D., \& Wright, С. (2019). Disrupting Climate Change Futures: Conceptual Tools for Lost Histories. Organization. https://doi.org/10.1177/1350508419883377

DOI: https://doi.org/10.1177/1350508419883377

Copyright (C) The Author(s) २०19. Reprinted by permission of SAGE Publications.

* This version of the article has been accepted for publication and undergone full peer review but has not been through the copyediting, typesetting, pagination and proofreading process, which may lead to differences between this version and the publisher's final version AKA Version of Record.

Uploaded to CBS Research Portal: May २०२० 


\title{
Disrupting climate change futures: Conceptual tools for lost histories
}

\author{
Christian De Cock
}

Daniel Nyberg

Christopher Wright

\begin{abstract}
Considering the worsening climate crisis, we argue that our present conditions require a particular approach to the past in order to disrupt current intellectual trajectories. We enrol Walter Benjamin's concept of history, via the writings of Svetlana Alexievich and Margaret Atwood, with the aim of bringing a criticality to the present to make us reconsider the ways we think about and act in our present world. Based on Alexievich and Atwood's work, we develop research conceptualizations of forgotten and alternative histories to open up a space to consider a future climate-changed world beyond the dominant tropes of inevitable dystopian apocalypse and clever technological adaptation. We offer the concept of 'hope without optimism' in encouraging management and organization studies scholars to develop a discipline fit for the Anthropocene.
\end{abstract}

Keywords: climate change; Anthropocene; literature; history; hope 
The climate crisis is now. Unprecedented hurricanes, storms, wildfires and droughts compete on nightly news bulletins as climate scientists' worst-case predictions of a decade ago have become our current reality. Despite the hope generated by the 2015 Paris Climate Agreement, ever-increasing greenhouse gas emissions and atmospheric concentrations of $\mathrm{CO}_{2}$ reemphasise the catastrophic nature of our situation (Tollefson, 2018). The Earth has already warmed by $1.1^{\circ} \mathrm{C}$ above pre-industrial levels and climate forcing from current emissions means that with at least another $0.6^{\circ} \mathrm{C}$ of warming in the pipeline we are already close to exceeding the Paris target of $1.5^{\circ} \mathrm{C}$ (Mann, 2014). Avoiding the politically-agreed 'dangerous' limit of $2^{\circ} \mathrm{C}$ thus looks increasingly unlikely (Anderson, 2015). Indeed, as Earth System scientists have argued, the climate crisis forms part of a broader process in which humans have fundamentally changed the physical basis of life on this planet; we have become geological actors living in a new epoch: the Anthropocene (Crutzen, 2002; Steffen, et al., 2007).

The existential nature of this issue has profound implications for Management and Organization Studies (MOS) research (Wright, et al., 2018). Even so, the MOS community remains remarkably sanguine about the climate crisis. The general approach within MOS has been to reframe the catastrophic meaning of climate change by considering it as simply another empirical space within which broader organizational theorizing can occur. The climate crisis is thus seen as an issue best located within the academic specialization of 'organizations and the natural environment' and specialist journals and academic divisions have developed to house such research (Bansal and Hoffman, 2012). The primary concern within this literature focuses on how business organizations can minimize risk and maximize opportunity in their interactions with natural resources and communities (Hart, 1997; Porter and Kramer, 2011). For instance, the academic and managerial fashion for organisational 'sustainability' suggests the possibility of balancing the business needs of profit-maximisation and shareholder value with the interests of the natural environment and local communities (Shrivastava, 1995). This 
'win-win' logic of course marginalises deeper and more radical criticism of the role of business and capitalism as central causes of the climate crisis (Wright and Nyberg, 2015).

This perspective also continues the dominant Western view of the world which upholds capitalism as the foundation for a utopian future based on new technologies and innovation. This idea of progress justifies a linear continuation of the present, with a particular past having priority in anticipating the future. Puig de la Bellacasa (2015: 693) has called this 'technoscientific futurity', 'a modern paradigm that associates the future with progress, with an ethico-political imperative to "advance" that remains solidly the orientation of linear, "progressivist", timelines'. This perspective sees no evident contradiction in the tensions between economic progress and environmental destruction. In this utopian view, the dominant political imaginary morphs into a continuation of our lifestyle based on technological innovations and climate engineering as if there were no victims of brutal resource capture, no suffering, and no creation of uninhabitable 'sacrifice zones' (Nixon, 2018: 13). This ignores not only 'other' humans who are exoticised and misrepresented (Said, 1978), but also the countless other species and habitats rapidly made extinct in this new era of the Anthropocene (Kolbert, 2014). The victims - both human and non-human - of this assumed progress, are the silenced Other; the past that is not present. It is a future of past victors celebrating consumption, identification with corporate brands, and the 'success' of capitalism. With the linearity of railway tracks, the dominant past is projected as the logical expectation for the future.

At the same time, a dystopian countervailing view has also emerged in MOS exploring corporate and organizational responses to the climate crisis (see e.g. Gosling and Case, 2013; Lederer and Kreuter, 2018; Wright and Nyberg, 2015). This more pessimistic writing suggests that social upheaval resulting from climate change enables capitalism to further strengthen its hold on societies (Wright, et al., 2018). Instead of utopian versions of green capitalism, the same trajectory leads to an apocalyptic future of disaster capitalism (Klein, 2007). This 
apocalyptic sentiment is perhaps best illustrated in films such as Elysium and Interstellar as well as the growing genre of climate fiction (cli-fi) literature (see e.g. Bacigalupi's (2015) The Water Knife and Kim Stanley Robinson's (2017b) New York 2140). These fictional stories depict a future where 'life is on the threshold of annihilation but where corporations are robust' (Colebrook, 2017: 103). However, this is not a fanciful future as many people in many places already experience a life on the brink of survival where resources are controlled by powerful elites. Thus, critics also appear to struggle to provide imaginaries beyond the stubborn linearity of current political thinking.

Indeed, Swyngedouw (2013) suggests that dystopian future imaginaries help to justify proposals for the capitalist 'crisis' management of climate change. Witness, for instance, the focus by corporations and celebrity billionaires such as Bill Gates and Richard Branson on geoengineering solutions to respond to the threat of climate change. Techno-management will be applied just in time so that 'we can safely continue shopping' (Swyngedouw, 2013: 10). Miéville (2018) recently went as far as to suggest that all the talk of interceding 'just in time' to avoid a catastrophic future does not just miss the point but is actively unhelpful, as it steers us away from the realization that we are already living in a worsening dystopia. The catastrophe of climate change is thus not a particular disaster that awaits us; we are in fact living through it now. Yet, dominant political and economic imaginaries evoke a notion of time that remains embedded in practices paced to a productivist ethos; where the fear of doom and the hope of adaptation have become co-dependent (Puig de la Bellacasa, 2017).

In this article, we argue that confronting the climate crisis requires an imaginative engagement with ideas of human and social organization in order to disrupt present thinking. Ghosh (2016: 111) argued in this context that 'our lives and our choices are enframed in a pattern of history that seems to leave us nowhere to turn but toward our self-annihilation', and, therefore, challenging the present conditions requires a critical re-appropriation of the past. In 
undertaking such a critical re-appropriation we turn first to the work of Walter Benjamin who, through the device of montage, aimed to revalue the ostensibly 'unimportant' elements of the past in order to bring about a displacement of the angle of vision (Eiland and Jennings, 2014). We follow our brief discussion of Benjamin's concept of history by considering two writers whose work embodies an alternative vision of history; Svetlana Alexievich's collections of oral histories of Soviet citizens (Alexievich, 2005; 2016) and Margaret Atwood's speculative fiction (Atwood, 1985; 2003; 2009b; 2013). This allows us to develop methods which cross traditional disciplinary boundaries and which vividly put Benjamin's vision into practice. This supports current projects on building counter-stories to challenge the hegemony of dominant histories in shaping alternative futures (Ergene, et al., 2018; Gayá and Phillips, 2016).

Our engagement with the writing of Alexievich and Atwood aims to bring forward alternative or 'minor' histories in order to derail the current intellectual trajectory. Minor history, as Stoler (2010: 7) suggests, 'marks a differential political temper and a critical space; it attends to structures of feeling and force that in "major" history might otherwise be displaced'. We thus join the body of work in MOS that turn to literature and different forms of writing to reimagine and question the dominant view of the world (see e.g. De Cock and Land, 2006; Phillips, 2014), and make conceivable 'what would otherwise remain hidden' (Iser, 1997: 4). These minor or hidden histories can generate affective knowledge; a knowledge that moves people to feel and act. We are thus hopeful that the connection with and the recognition of past emotions, experiences and memories can propel 'our' research community to take responsibility for living in the Anthropocene. 


\section{Bringing history to a standstill}

In challenging the idea of a linear, progress-oriented view of time - an idea which supports positions across the political spectrum; from fascism, to capitalism, to Marxism - we turn to the thought-world of Walter Benjamin. Almost paradoxically, in trying to keep open the possibility of the future that is not simply an extension of the present, Benjamin purposefully turned towards an 'excavation of the past' so as to create an image of truth 'that might illuminate the situation of contemporary events' (Featherstone, 2005: 318). However, this is not about a simple restitution of the past which seems to be a pre-occupation of the conservative revolution that has swept Europe and the USA, and neither is the past expected to yield some metaphysical truth that can be neatly fitted within a narrative of progress. For Benjamin, it is precisely a consciousness of the very otherness of the past that allows it to bring the present into a critical condition in which we feel compelled to intervene. This means re-establishing the meaning of the past outside the framework of tradition and received historical narratives.

The crucial point in Benjamin's view of history is that there lies a meaning in the past that can only be recognized at a future point, when the image of the past is 'flashing up in the now of its recognizability' (Benjamin, 2002: 473), and past and present enter into a constellation with each other. In Benjamin's words: 'It is not that what is past casts its light on what is present, or what is present its light on what is past; rather, the image is that wherein what has been comes together in a flash with the now to form a constellation' (p. 463). This is the moment where the dream of history as progress comes to a standstill; a moment that does not allow itself to be enveloped in an ongoing historical narrative but where the montage of past and present allows the yet unperceived significance of the past to appear as a force in the present. Benjamin thus speaks of the 'increasing concentration (integration) of reality', such that elements of the past can acquire a higher grade of actuality than they had in the moment of their existing. This actualization of former contexts, "puts the truth of all present action to 
the test. Or rather, it serves to ignite the explosive materials that are latent in what has been' (p. 392).

Benjamin's fragmentary historiography consisted in identifying the moments of rupture, displacement and dislocation in history and the redemption from oblivion of those elements of the past that illuminate our situation, thus liberating their hidden energies for the sake of a future to come. It is the defeats and catastrophes of the past that crushed the hopes of those who have gone before - what has become forgotten, concealed or displaced - that might provide the motivation for political action in the present (Featherstone, 2005). Yet, it is only through what Arendt (1968: 201), with explicit reference to Benjamin, called 'the deadly impact of new thoughts' that this marginalized past can be critically re-appropriated. This requires asking the right questions of the past, so that it may 'open up to us with unexpected freshness and tell us things no one has yet had ears to hear' (Arendt, 1993: 241). Through a careful montage, fragments of the past can be temporarily restored to a living context; not the temporal context from which they were taken but a context of experience.

We will now briefly explore the work of two authors who, perhaps unwittingly and in their own particular ways, actualize Benjamin's ideas on history and catastrophe. Both Alexievich and Atwood practice a form of Benjaminian montage of moments past, future and present, which brings a criticality to the present. Their writing, in different ways, offer the possibility of history to disrupt the experiences of the present in order to open up a space for climate change futures (Wright, et al., 2013), beyond the dominant tropes of dystopian apocalypse and clever technological adaptation, either of which project a belief of living the present historical moment without much change or major discomfort. 
Svetlana Alexievich: the history of utopia

I have written five books, but I feel that they are all one book. A book about the history of a utopia... So what is it that I do? I collect the everyday life of feelings, thoughts, and words. I collect the life of my time... the things that the big picture of history usually omits, or disdains. I work with missing history. (Alexievich, 2015: 5-7).

In 2015 Svetlana Alexievich won the Nobel Prize for literature for her collection of oral histories exploring the suffering and loss of citizens from the former Soviet Union. These works document the profound impact that the stripping away of a socio-political identity had, both on the population at large, and at a personal level. Focusing on points of trauma, such as the SovietAfghan war (Alexievich, 1992), the Chernobyl nuclear disaster (Alexievich, 2005), and the collapse of the USSR (Alexievich, 2016), Alexievich seeks to 'chase the catastrophe into the framework of the everyday and try to tell a story' (Shayevich, 2015: np). In the book SecondHand Time (Alexievich, 2016), she gives voice to people who felt betrayed, cheated out of their lives, with their suffering becoming a form of information as she traces an affective history of the Soviet people. One of her hundreds of interviewees suggests:

We sit atop the ruins of socialism like it's the aftermath of war. We're run down and defeated. Our language is the language of suffering... We haven't understood a thing about the world we'd only recently been living in and yet we're already living in a new one. An entire civilization lies rotting on the trash heap. (p. 38)

Second-Hand Time is divided into two parts: 'Consolation of the Apocalypse', covering the years 1991-2001 as the Soviet Union fell apart, and 'The Charms of Emptiness' which spans the years 2002-2012 during which Putin consolidated his power. Both parts symmetrically open with a section called 'snatches of street noise and kitchen conversations' (2016: 15-39; 285- 
303), offering a gamut of short individual stories. This is followed by notes of longer conversations with many people scattered across the former USSR, allowing extended monologues to unfurl. Through the technique of montage Alexievich highlights the entanglement of the individual and the collective, subtly suggesting that whilst any voice is highly individual, any other voice could have been singled out to yield a similar story. The power of her way of writing history stems from her ability to compose many voices into an expressive overall construct all her own, with the ultimate aim of somehow redeeming her country (Solovieva, 2018). This redemption starts with the task of understanding 'what happened to us.' Or as Alexievich (2015: 8) put it in her Nobel prize acceptance speech:

We haven't had time to comprehend what already has and is still happening to us, we just need to say it. To begin with, we must at least articulate what happened. We are afraid of doing that, we're not up to coping with our past.

In her particular use of montage, Alexievich implicitly follows Benjamin's goal of reestablishing the meaning of the past outside of received historical narratives. She transforms the flotsam and jetsam of Soviet history as recorded in her interviews into a collective process of thinking-through. It is this finely calibrated constellation of voices and images that provides a meta-language that interrupts the received official view of history, bringing it to a standstill. In a revealing passage of Voices From Chernobyl (Alexievich, 2005: 26) she explicitly expresses the view that it is only in the present that individual fragments from a rapidly receding past can reveal meaning:

Unable to find the words for these new feelings and emotions, unable to find emotions for these new words, we no longer knew how to express ourselves; but we were gradually immersed in the atmosphere of a new way of thinking, and so it has become possible today to pinpoint our state at the time. 
Alexievich details how deeply the psychological and social operation of Soviet ideology became rooted in human nature. For decades an ideology oriented towards a glowing future, in the name of which so much havoc was wreaked, had also sustained the identities of both victims and perpetrators of violence and helped them survive: 'our entire tragedy lies in the fact that our victims and executioners are the same people' (2016: 263). The utopian project shows how life under these circumstances would have been unbearable if it had not been covered up by the cloying optimism of Soviet ideology. When that ideology collapsed what disappeared with it was the sense that some grand purpose reigned over the horrors that people went through together (Solovieva, 2018). At that moment, dreams of a progressive future left behind only the consciousness of futility as people were left stranded in a world they could no longer make sense of. Reflecting on both the collapse of the Soviet Union and Chernobyl, Alexievich (2005: 24) writes in an introductory reflection, called 'The author interviews herself on missing history and why Chernobyl calls our view of the world into question':

...our minds just wanted to capitulate. It was a cataclysm for our minds. The world of our beliefs and values had been blown apart...Thus we've ended up living in one world, while our minds remain stuck in another. Reality slips away; our consciousness doesn't have room for it. That's right. We can't catch up with reality. (p.32)

Alexievich invites us to share the experiences of the collapse of a society by paying attention to the ruptures that made the present in the name of progress. By listening to the voices of her interviewees, we can prepare ourselves for our own grief, a grief that that does not fit in the progress narrative of technofuturity ${ }^{1}$. The Soviet citizens she interviews lost everything that many people in the Western world are about to lose: a familiar way of life; an

\footnotetext{
${ }^{1}$ As Nixon (2018:14) puts it rather pointedly: 'And so the ecomodernists become the grief police: no mourning permitted here, move on already, you're creating an inadmissible disturbance.'
} 
economic system that guaranteed security; an ideology that gave them moral certainties and covered over ethnic divisions. Anna M who describes herself in her conversation with Alexievich as a 'chunk of sovok'2 (2016: 266) exclaims: 'Our country doesn't exist anymore and it never will, but here we are... old and disgusting... with our terrifying memories and poisoned eyes... We're right here!' (2016: 255). We in capitalist liberal democracies seem permanently bound to our own ideology of technoscientific futurity, but are we already living in the ruins of a lost world?

How then can we start mourning consumer capitalism and express the loss we will feel in a climate-ravaged world? Of course, the expressions of grief collected by Alexievich do not map precisely on the ambiguous loss involved in climate grief where the object of our attachment is still physically present but slowly disappearing. But as ever, the questions raised through thinking about grief are more important than any precise answers. As Alexievich points to the layered temporalities of living and dying that shape our world, her writing helps us see the present in a different light and assists us in understanding and preparing for the experience of events currently unfolding. As she notes in her haunting description at the end of the introduction to Voices from Chernobyl:

What lingers most in my memory of Chernobyl is life afterwards: the possessions without owners, the landscapes without people. The roads going nowhere, the cables leading nowhere. You find yourself wondering just what this is: the past or the future. It sometimes felt to me as if I was recording the future (2005: 33).

\footnotetext{
${ }^{2}$ In a footnote, the translator, Bela Shayevich, describes how "this is a widely used pejorative term for one who adheres to Soviet values, attitudes and behaviours. "Sovok" can also refer to the Soviet Union itself. It's a pun on the word for "dustpan"' (Alexievich, 2016: 3).
} 


\section{Margaret Atwood: montaged futures}

My rules for The Handmaid's Tale were simple: I would not put into this book anything that humankind had not already done, somewhere, sometime, or for which it did not already have the tools. (Atwood, 2011: 88)

In thinking about Margaret Atwood and climate change, it is perhaps her MaddAddam trilogy of speculative fiction set in a post-apocalyptic Earth, that most readily comes to mind (Atwood, 2003; 2009b; 2013). In this trilogy Atwood depicts a future world ravished by climate change and catastrophic misuses of biotechnology. In developing her post-apocalyptic narrative, she follows a recurring trope in science fiction of an intense concern for environmental issues, starting in the 1970s when a spate of feminist science fiction novels was published by authors such as Marge Piercy, Joanna Russ and Ursula Le Guin (Ferreira, 2001). In turn, feminist ecophilosophers such as Donna Haraway (2016) and Elizabeth Povinelli (2016) ${ }^{3}$ have explicitly acknowledged their intellectual debt to these science fiction writers.

The starting place of the first novel of the trilogy, Oryx and Crake, is at some point in the future, where a character called Snowman is contemplating the devastated landscape around him. Most of humanity is dead and he is one of the few survivors scrabbling out a hopeless existence in the aftermath of a yet unnamed apocalypse, which we learn later was caused by a man-made virulent plague. The similarities between Atwood's fictional and Alexievich's nonfictional descriptions of a desolate apocalyptic landscape are difficult to ignore, and so is their underlying cause: human innovation run amok. Interwoven with Snowman's struggles for survival in this unforgiving world is the story of his past as a young man named Jimmy. Jimmy's world is really our own 21 st-century society, with its most repugnant aspects amplified. The Year of the Flood explores the world of Oryx and Crake from a different

\footnotetext{
${ }^{3}$ Povinelli (2016) suggests that academic disciplines are only now catching up with a conversation begun in literature, singling out in particular Margaret Atwood's The Handmaid's Tale and her MaddAddam Trilogy.
} 
perspective whilst covering the same time period. Whereas Jimmy/Snowman has grown up within a privileged technocratic enclave, The Year of the Flood gives us the view from below, its pre-disaster plot unfolding in neighbourhoods that the security forces do not even bother to patrol and where the law of the jungle reigns. Thus, we have a double gauging and mapping of what is an extreme version of our own Western society. We witness in these novels the future of capitalist society in which various private corporations oversee the outsourcing of social needs. These corporations own all science and technology in the service of furthering capitalist growth while destroying the ecological balance of the planet.

Whilst she may be uncomfortable with the label (e.g. Atwood, 2011), Atwood deploys a typical science-fiction device in the Maddaddam trilogy where the present is 'transformed into a distant past by a future perspective whose true function and reason for being is merely and precisely to be the operator of just such a shift in tense perspectives' (Jameson, 2005: 382). Atwood takes trends and bits of information from our present whose meaning and consequences are revealed in the present of Snowman, which lies in our future. This is where the ideology of technofuturity might lead us, Atwood suggests. Robinson (2017a: np) describes this approach to history with an analogy of 3-D glasses:

Through one lens you see a legitimate attempt to imagine a possible future (a prediction); through the other lens you're looking at a surrealist or symbolic version of our present moment (a metaphor). When the two images fuse, the 3D that pops in your mind is temporal rather than spatial - it's history. (emphasis added).

What makes Atwood speculative fiction particularly interesting is that she imagines nothing we have not already invented or started to invent. Everything that happens in her novels is possible and may even have already happened. In her books there is no technology not already available, 'no imaginary gizmos, no imaginary laws, no imaginary atrocities' (Atwood, 2017). 
This montage approach was first displayed in her earlier book The Handmaid's Tale (1985) with the story set in a future tyrannical republic called Gilead, which is governed by a theocracy which rules ruthlessly over a shrinking population brought about through ecological destruction. This ruling class have fertile females assigned to them as 'Handmaids' in monopolized reproduction. In writing this account of a totalitarian future Atwood drew on a huge box of clippings about, amongst others, the politics of abortion, group executions, the history of slavery and American polygamy, the Lebensborn programme of the SS and the childstealing by the Argentine generals, as well as reports on ecological disasters and pollution (Atwood, 2017). Her method is like Alexievich's, in that she assembles the debris of history, the bits that fit awkwardly into 'official' history. Atwood also describes how she started work on The Handmaid's Tale when she was living in Berlin, where she made several visits to the Eastern Bloc and 'thus had several first-hand experiences of the flavour of life in a totalitarian - but supposedly utopian - regime' (Atwood, 2011: 86-87). The ingenuity of Atwood lies in her uses of the past to provide an imaginary that criticizes 'the ideology of the present, and ideology of the future now' (Augé, 2014: 3). The Handmaid's Tale and the MaddAdam trilogy do not simply assist us in learning from the past to understand the present; they address headon the key question Gan et al. (2017: G4) put to us: 'How shall we retain the productive horror of our civilization and yet refuse its inevitability?'. Through her montage, Atwood shows the horrors of the past in the future, which allow us to choose otherwise.

In this openness for an alternative lies an interesting aspect of Atwood's writing that is critical in building research for a different future: hope. Le Guin (2009), in her review of The Year the Flood, considered that at the hidden heart of the novel lies 'a vast, irrational hope... irrational affirmation'. Atwood herself identified two instances of hope in The Handmaid's Tale: 
'One is in the past - the past that is our own present. The second is placed in a future beyond the main story by the Afterword at the end of the book, which describes a future in which Gilead... has ended, and has thus become a subject for conferences and academic papers' (Atwood, 2011: 91).

The novel is composed as a record of events written by the main character Offred, that she hides in the hope that it might be discovered in the future. Her record-keeping is spurred by finding a message from her predecessor scratched into the floor of her cupboard (a schoolboy Latin joke - 'nolite te bastardes carborundorum'). This small act of resistance from the past, gives Offred hope that her own narrative may be uncovered in the future.

For Atwood (2017) the record of witnessing is an act of hope in that it implies a future reader. She also developed this idea in the non-fiction book Payback: Debt and the Shadow Side of Wealth (2009a) in which she outlined the various responses to the $14^{\text {th }}$ century Black Death. Some sought to outrun the plague or secluded themselves in castles, others sacrificed themselves willingly to help the sick. Some saw the plague as an excuse for drinking, partying, raping and murdering, while others sought to bear witness to the event and keep records. This latter response to the plague is arguably important in understanding the Anthropocene; describing and explaining the current experiences of climate change may provide materials for the future, a future with which our present may form a critical constellation.

A such, Atwood's speculative fiction provides a playful methodology to imagine alternatives when we can no longer rely on the dominant political myths of corporate capitalism. Her writing avoids the linearity common in both utopian and dystopian futures and theorizations, with both scenarios serving as positive or negative fixed destinations, without ever confronting the present hegemonic worldview (Kallis and March, 2015). In contrast, Atwood's montages of alternative futures are assemblages of many temporal layers. The 
heterogeneous elements of Atwood's fiction break with the linearity of history and offer futures useful in the present.

\section{Discussion: in search of tomorrow's brains}

The history of disasters has begun. But people do not want to reflect on that, because they have never thought about it before, preferring to take refuge in the familiar. And in the past. (Alexievich, 2005: 27-28)

Sebald (2004), in an essay on the devastating firebombing of German cities at the end of the Second World War, documented how people were unable to assess the danger they found themselves in. They carried on with their usual roles as if nothing dramatic was happening, overlooking what was taking place before their eyes. Their idea of 'normal' time and their sensory experience of time became very much at odds as the catastrophe unfolded. Yet, instead of simply expressing incredulity, Sebald reflected that these people 'could not have devised practicable emergency measures... except with tomorrow's brains (p.63).' It is precisely in finding a surrogate for 'tomorrow's brains' that can process the temporal and spatial vastness of the climate emergency that we believe our two authors have important critical conceptual tools to offer us, now that our own reality is beginning to break down.

The 'history of disasters' Alexievich alludes to, would mean in the context of climate catastrophe that we have reached, 'the point at which we shall drop out of what we have thought for so long to be our autonomous history and back into the history of nature' (Sebald, 2004: 66). As the climate catastrophe unfolds, it will shake the very idea of what it means to be human ever more profoundly. Nixon (2018: 5), for example, points out that, 'the Anthropocene has profound implications for the meaning and object of history, reframing the future by rethinking the past as shaped by a fused biological-geological actor', adding that we do not exercise our geological power 'in a state of segregation from the actions of other forces' (p.14). Feminist 
philosophers such as, Elizabeth Povinelli and Elizabeth Grosz have developed concepts to address this fusion of the biological and the geological. Povinelli (2016) coined the concept of 'geontology' ${ }^{4}$ to explore the interpenetration of biography and geography, whilst Grosz uses the notion of 'geopower' as a way of characterizing the geological, inhuman and preindividuated forces that subtend organic life (Yusoff, et al., 2012). This attention to the meshing of organic and nonorganic life is important Grosz argues because:

Unless the bigger questions about how to think about the earth...time and history, are also asked, we will remain stuck in activisms that are merely reactive - against patriarchy, against sexual normalization, against the colonial or the global - rather than fully creative and capable of inventing new ways of collective life. (Grosz, et al., 2017: 140)

Yet, as we are becoming aware of both our own geologic powers and the vast forces emanating from the environment, we still lack 'tomorrow's brains' to conceive of the human consequences across a vastly expanded temporal stage, something which is painfully evoked by Alexievich:

When we talk about the past or the future, we read our ideas about time into those words; but Chernobyl is, above all, a catastrophe of time. The radionuclides strewn across our earth will live for 50,000, 100,000, 200,000 years. And longer. From the perspective of human life, they are eternal. What are we capable of comprehending? Is it in our power to extract and decipher the meaning of this still unfamiliar horror? (Alexievich, 2005: 24)

\footnotetext{
${ }^{4}$ As Povinelli elaborates, '... the point of the concept of geontology... is not to found a new ontology of objects... nor to adjudicate the possibility or impossibility of the human ability to know the Truth of the world of things. Rather they are concepts meant to help make visible the figural tactics of late liberalism as a longstanding bioontological orientation and distribution of power crumbles, losing its efficacy as a self-evident backdrop to reason"' (Povinelli, et al., 2017: 173).
} 
The self-evident demarcations between the human and nonhuman, between life descriptions and non-life descriptions, thus have to be questioned under the emerging conditions of the climate catastrophe. In this context, our authors stimulate new forms of noticing that may help us to 'think through cultural and ethical logics that we have yet to encounter' (Gosling and Case, 2013: 707), with texts communicating and conveying affect (Gayá and Phillips, 2016). When Alexievich found herself inside the Chernobyl exclusion zone, she related how she felt everything had been stripped away from her so that she was not an individual but simply 'a representative of a biological species that could be destroyed' (Alexievich, 2015). In looking back in grief, an interviewee in Second-Hand Time collapses the distinction between the human and nonhuman in heartbreaking fashion: 'I'm talking about our old life. I don't feel sorry for myself, I feel bad for everything we used to love' (2016: 102). Atwood is more playful with the human-nonhuman distinction as she describes strange genetic hybrids created at OrganInc Farms, where Jimmy's father works. These include creatures such as the libam (half lion, half lamb) and the strangely intelligent and bloodthirsty pigoons (a combination of pig and human genes). Genetic engineering reaches its apogee in her novels in the beautiful, innocent greeneyed Crakers. With their skins resistant to ultraviolet light and little interest in sex or violence, they are quasi-humans constructed so that they will never suffer from the ills that plagued Homo Sapiens and serve as models for a more perfect race, a race that has inherited a devastated planet.

Alexievich and Atwood's writings are ultimately concerned with the conditions that contribute to the (in)visibility and (un)intelligibility of our physical and social arrangements. Their vivid descriptions of perseverance, endurance and precarious survival offer a sharp contrast to the grand narrative of progress, with its twin imaginaries of inevitable dystopian 
apocalypse $^{5}$ and clever technological adaptation, which underpin so much of our thinking. Walter Benjamin (2002), writing in the 1930s, presciently remarked that, 'Overcoming the concept of "progress" and overcoming the concept of "period of decline" are two sides of one and the same thing' (p. 460). He called progress a 'phantasmagoria of history,' in which humankind figures 'as one of the damned' (Tiedemann, 2002: 939). One of the key objectives of his work then was to 'annihilate within itself the idea of progress... Its founding concept is not progress but actualization' (Benjamin, 2002: 460). We need to present history in such a way as to lead the past to 'bring the present into a critical state' (p. 471) in which we feel compelled to intervene; to 'blast the epoch out of the reified continuity of history' (p. 474), and the means to do so Benjamin found in the flotsam and jetsam of history.

Both our authors certainly entice us to think about our world differently by bringing to light aspects of that world that normally would simply disappear in official accounts. As Alexievich (2016: 9) reflects on trying to write about the Soviet Union, 'I'm searching for a language... There's even a difference between the way people speak in the morning and how they speak at night. What happens between two people at night vanishes from history without a trace.' The thrust of their work is very much Benjaminian in that it is not simply about 'learning from history'; rather it is about challenging the grid of narrative forms and conventions that constrain our imagination. They employ 'minor' histories to construct an affective aporia - an experienced contradiction and logical disjunction in what we are doing that can disrupt the current state of affairs we outlined at the start of this article. These histories bring to light a non-correspondence between what is claimed by powerful social actors and

\footnotetext{
${ }^{5}$ This imaginary was vividly captured in a review article by Zadie Smith (2013: np): 'Imagining that reality - in which everybody (except me) becomes a corpse - presents no difficulties whatsoever. Like most people in New York City, I daily expect to find myself walking the West Side Highway with nothing but a shopping cart stacked with bottled water, a flashlight, and a dead loved one on my back, seeking a suitable site for burial. The post-apocalyptic scenario - the future in which everyone's a corpse (except you) - must be, at this point, one of the most thoroughly imagined fictions of the age.'
} 
what people have actually experienced, and thus help to collapse categories that allow the world claimed by corporate capitalism to appear as the actual world (Povinelli, 2011). Dorris Lessing (1974: 20) expressed rather beautifully this affective aporia in another prescient example of fiction:

This is the sort of thing we accepted as normal. Yet for all of us there were moments when the game we were all agreeing to play simply could not stand up to events: we would be gripped by feelings of unreality, like nausea... Perhaps our tacit agreement that nothing much, or at least, nothing irrecoverable, was happening, was because for us the enemy was Reality, was to allow ourselves to know what was happening. (p. 20).

\section{Conclusion: hope without optimism}

The Future is once again, not where it ought to be. Our time comes to us secondhand (Alexievich, 2016: 11).

In Second-Hand Time Alexievich describes how over a seventy-year period the Marxist-Leninist laboratory gave rise to a new 'man', Homo sovieticus, who was ultimately a tragic figure. Does the capitalist system that has spawned the climate catastrophe not sustain the identities of its citizens, including those of organizational scholars, in equally tragic ways? As we noted at the outset, existing MOS scholarship remains trapped within a linear conception of time in which the dominant past of capitalist progress is reified into a future of utopian 'green business' on the one hand (Hart, 1997; Porter and Kramer, 2011), or a dystopian world of disaster capitalism on the other (Klein, 2007). With our practices and identities caught up in the projection of a dominant past, how can we in the MOS community distance ourselves from what we are currently doing and develop new relations and identities that interrupt this linear intellectual trajectory? And what can we legitimately hope for as we plummet towards a world 
where the whole structure of evaluating our current world might cease to make sense (Gosling and Case, 2013; Nixon, 2018); a place where we will find the future is no longer where it ought to be?

The valuable aspects of Alexievich's and Atwood's writing for MOS is how they play with the intersection history/literature. This is used to challenge dominant understandings of the past and to contest established truth in organizational scholarship (De Cock, 2009). There exist of course also minor histories within MOS to assist us in challenging the field's dominant trajectory by showing the relevance of the past to understand or critique the present (Godfrey, et al., 2016), or to provide a retrospective interpretation of the past (Suddaby and Foster, 2017). This includes voices and experiences outside a narrow modern Western management trajectory that are rarely accounted for (see e.g. Cooke, 2003 on the omission of slavery). For example, from a post-colonial perspective, Banerjee (2011) collects voices from different indigenous communities forced to give up their sovereignty, autonomy and tradition in favour of Western models of resource extraction and 'progress'. These are voices left behind and by revisiting them we can question who is empowered and authorized to imagine futures.

Turning to Alexievich and Atwood builds on this work by providing concepts and modes of writing and researching that critically engage the current organization of the actual. These authors offer us examples of 'lost' times, thus assisting us in thinking about the conditions of liveability in our own dangerous times and learning to account for, "where people are left, what they are left with, and what means they have to deal with what remains' (Stoler, 2013: 24). Their focus on the horrors of history provide us with hope by exclaiming 'not this!' whilst at the same time demonstrating sheer persistence in the face of catastrophe. They open up for the reader a prospect onto history from which the false glimmer of categories such as coherence and progress have been stripped away. Theirs is a 'hope without optimism': a particular species of hope that is no longer connected to an expected success, but which tries 
to keep open the space for difference, for the future as a time-yet-to-come. Walter Benjamin, writing in 1933 whilst facing his own impending doom, described this 'hope without optimism' as a 'total absence of illusion about the age and at the same time an unlimited commitment to it' (quoted in Eiland and Jennings, 2014: 413). It is precisely such a 'hope without optimism' that we suggest can jolt organizational scholars out of their far too sanguine approach to climate change and encourage us to develop management and organization studies as a discipline fit for the Anthropocene. After all, as Miéville (2018: np) put it rather viscerally, 'it is worth fighting even for ashes, because there are better and much, much worse ways of being too late. Because and yet. This shit is where we are. A junk heap of history and hope'. 


\section{References}

Alexievich, S. (1992) Zinky Boys: Soviet Voices from a Forgotten War. New York: W.W. Norton \& Co.

Alexievich, S. (2005) Voices from Chernobyl: The Oral History of a Nuclear Disaster. Chicago, IL: Dalkey Archive Press.

Alexievich, S. (2015) Nobel Lecture by Svetlana Alexievich. Stockholm: Svenska Akademien.

Alexievich, S. (2016) Secondhand Time : The Last of the Soviets. New York: Random House.

Anderson, K. (2015) 'Duality in Climate Science', Nature Geoscience, 8(12): 898-900.

Arendt, H. (1968) Men in Dark Times. New York: Harcourt Brace Jovanovich.

Arendt, H. (1993) Between Past and Future: Eight Exercises in Political Thought. New York: Penguin Books.

Atwood, M. (1985) The Handmaid's Tale. Toronto: McClelland \& Stewart.

Atwood, M. (2003) Oryx and Crake. London: Bloomsbury.

Atwood, M. (2009a) Payback: Debt and the Shadow Side of Wealth. London: Bloomsbury.

Atwood, M. (2009b) The Year of the Flood. London: Bloomsbury.

Atwood, M. (2011) In Other Worlds: SF and the Human Imagination. London: Virago.

Atwood, M. (2013) Maddaddam. London: Bloomsbury.

Atwood, M. (2017) 'Margaret Atwood on What "The Handmaid's Tale" Means in the Age of Trump', The New York Times. https://www.nytimes.com/2017/03/10/books/review/margaret-atwood-handmaids-tale-age-oftrump.html.

Augé, M. (2014) The Future. London: Verso.

Bacigalupi, P. (2015) The Water Knife. New York: Penguin.

Banerjee, S.B. (2011) 'Voices of the Governed: Towards a Theory of the Translocal', Organization, 18(3): 323-44.

Bansal, P. and Hoffman, A.J. (eds). (2012) The Oxford Handbook of Business and the Natural Environment. Oxford: Oxford University Press.

Benjamin, W. (2002) The Arcades Project. Cambridge, MA: Harvard University Press.

Colebrook, C. (2017) 'Anti-Catastrophic Time', New Formations, 92: 102-19.

Cooke, B. (2003) 'The Denial of Slavery in Management Studies', Journal of Management Studies, 40(8): 1895-918. 
Crutzen, P.J. (2002) 'Geology of Mankind: The Anthropocene', Nature, 415(6867): 23.

De Cock, C. (2009) 'Jumpstarting the Future with Fredric Jameson: Reflections on Capitalism, Science Fiction and Utopia', Journal of Organizational Change Management, 22(4): 437-49.

De Cock, C. and Land, C. (2006) 'Organization/Literature: Exploring the Seam', Organization Studies, 27(4): 517-35.

Eiland, H. and Jennings, M.W. (2014) Walter Benjamin: A Critical Life. Cambridge, MA: Belknap Press.

Ergene, S., Calás, M.B. and Smircich, L. (2018) 'Ecologies of Sustainable Concerns: Organization Theorizing for the Anthropocene', Gender, Work \& Organization, 25(3): 222-45.

Featherstone, M. (2005) 'Ruin Value', Journal for Cultural Research, 9(3): 301-20.

Ferreira, M.A. (2001) 'Organizing Men out in Joanna Russ's the Female Man and Fay Weldon's the Cloning of Joanna May', in W. Smith, M. Higgins, M. Parker and G. Lightfoot (eds) Science Fiction and Organization, pp. 73-89. London: Routledge.

Gan, E., Tsing, A., Swanson, H. and Bubandt, N. (2017) 'Haunted Landscapes of the Anthropocene', in A. Tsing, H. Swanson, E. Gan and N. Bubandt (eds) Arts of Living on a Damaged Planet, pp. G1-G14. Minneapolis, MN: University of Minnesota Press.

Gayá, P. and Phillips, M. (2016) 'Imagining a Sustainable Future: Eschatology, Bateson's Ecology of Mind and Arts-Based Practice', Organization, 23(6): 803-24.

Ghosh, A. (2016) The Great Derangement: Climate Change and the Unthinkable. Chicago, IL: University of Chicago Press.

Godfrey, P.C., Hassard, J., O'Connor, E.S., Rowlinson, M. and Ruef, M. (2016) 'What Is Organizational History? Toward a Creative Synthesis of History and Organization Studies.', Academy of Management Review, 41(4): 590-608.

Gosling, J. and Case, P. (2013) 'Social Dreaming and Ecocentric Ethics: Sources of NonRational Insight in the Face of Climate Change Catastrophe', Organization, 20(5): 705-21.

Grosz, E., Yusoff, K. and Clark, N. (2017) 'An Interview with Elizabeth Grosz: Geopower, Inhumanism and the Biopolitical', Theory, Culture \& Society, 34(2-3): 129-46.

Haraway, D.J. (2016) Staying with the Trouble: Making Kin in the Chthulucene. Durham, NC: Duke University Press.

Hart, S.L. (1997) 'Beyond Greening: Strategies for a Sustainable World', Harvard Business Review, 75(1): 66-77.

Iser, W. (1997) 'The Significance of Fictionalizing', Anthropoetics, III(2): 1-9.

Jameson, F. (2005) Archaeologies of the Future: The Desire Called Utopia and Other Science Fictions. London: Verso. 
Kallis, G. and March, H. (2015) 'Imaginaries of Hope: The Utopianism of Degrowth', Annals of the Association of American Geographers, 105(2): 360-68.

Klein, N. (2007) The Shock Doctrine: The Rise of Disaster Capitalism. New York: Picador.

Kolbert, E. (2014) The Sixth Extinction: An Unnatural History. New York: Henry Holt.

Le Guin, U.K. (2009) 'The Year of the Flood by Margaret Atwood', The Guardian. 29 August, https://www.theguardian.com/books/2009/aug/29/margaret-atwood-year-of-flood.

Lederer, M. and Kreuter, J. (2018) 'Organising the Unthinkable in Times of Crises: Will Climate Engineering Become the Weapon of Last Resort in the Anthropocene?', Organization, 25(4): 472-90.

Lessing, D. (1974) The Memoirs of a Survivor. London: Octagon Press.

Mann, M. (2014) 'False Hope: The Rate of Global Temperature Rise May Have Hit a Plateau, but a Climate Crisis Still Looms in the near Future', Scientific American, 310(4): 78-81.

Miéville, C. (2018) 'A Strategy for Ruination', Boston Review: A political and literary forum. January, http://bostonreview.net/literature-culture-china-mieville-strategy-ruination.

Nixon, R. (2018) 'The Anthropocene: The Promise and Pitfalls of an Epochal Idea', in G. Mitman, M. Armiero and R. Emmett (eds) Future Remains: A Cabinet of Curiosities for the Anthropocene, pp. 1-18. Chicago: University of Chicago Press.

Phillips, M. (2014) 'Re-Writing Corporate Environmentalism: Ecofeminism, Corporeality and the Language of Feeling', Gender, Work \& Organization, 21(5): 443-58.

Porter, M.E. and Kramer, M.R. (2011) 'Creating Shared Value', Harvard Business Review, 89(1/2): 62-77.

Povinelli, E.A. (2011) Economies of Abandonment: Social Belonging and Endurance in Late Liberalism. Durham, NC: Duke University Press.

Povinelli, E.A. (2016) Geontologies: A Requiem to Late Liberalism. Durham, NC: Duke University Press.

Povinelli, E.A., Coleman, M. and Yusoff, K. (2017) 'An Interview with Elizabeth Povinelli: Geontopower, Biopolitics and the Anthropocene', Theory, Culture \& Society, 34(2-3): 169-85.

Puig de la Bellacasa, M. (2015) 'Making Time for Soil: Technoscientific Futurity and the Pace of Care', Social Studies of Science, 45(5): 691-716.

Puig de la Bellacasa, M. (2017) Matters of Care: Speculative Ethics in More Than Human Worlds. Minneapolis, MN: University of Minnesota.

Robinson, K.S. (2017a) 'How Will New York Cope with Climate Change?', Chicago Review of Books. 6 March, https://chireviewofbooks.com/2017/03/06/kim-stanley-robinson-how-willnew-york-cope-with-climate-change/.

Robinson, K.S. (2017b) New York 2140. New York: Little Brown \& Co. 
Said, E.W. (1978) Orientalism. London Routledge \& Kegan Paul.

Sebald, W.G. (2004) On the Natural History of Destruction. New York: Modern Library.

Shayevich, B. (2015) 'Svetlana Alexievich Builds Individual Voices into a Mighty Chorus', The Guardian. 9 October, https://www.theguardian.com/books/booksblog/2015/oct/08/svetlana-alexievich-buildsindividual-voices-into-a-mighty-chorus.

Shrivastava, P. (1995) 'The Role of Corporations in Achieving Ecological Sustainability', Academy of Management Review, 20(4): 936-60.

Smith, Z. (2013) 'Man Vs. Corpse', The New York Review of Books. 5 December, https://www.nybooks.com/articles/2013/12/05/zadie-smith-man-vs-corpse/.

Solovieva, O.V. (2018) 'Memory in Forgetful Times: Review of Svetlana Alexievich's Secondhand Time: The Last of the Soviets', Boundary2. 26 March, https://www.boundary2.org/2018/03/olga-v-solovieva-memory-in-forgetful-times-review-ofsvetlana-alexievichs-secondhand-time-the-last-of-the-soviets/.

Steffen, W., Crutzen, P.J. and McNeill, J.R. (2007) 'The Anthropocene: Are Humans Now Overwhelming the Great Forces of Nature?', AMBIO: A Journal of the Human Environment, 36(8): 614-21.

Stoler, A.L. (2010) Along the Archival Grain: Epistemic Anxieties and Colonial Common Sense. Princeton, NJ: Princeton University Press.

Suddaby, R. and Foster, W.M. (2017) 'History and Organizational Change', Journal of Management, 43(1): 19-38.

Swyngedouw, E. (2013) 'Apocalypse Now! Fear and Doomsday Pleasures', Capitalism Nature Socialism, 24(1): 9-18.

Tiedemann, R. (2002) 'Dialectics at a Standstill: Approaches to the Passagen-Werk', in R. Tiedemann (ed) Walter Benjamin: The Arcades Project, pp. 929-45. Cambridge, MA: Harvard University Press.

Tollefson, J. (2018) 'Can the World Kick Its Fossil-Fuel Addiction Fast Enough?', Nature, 556(7702): 422-25.

Wright, C. and Nyberg, D. (2015) Climate Change, Capitalism and Corporations: Processes of Creative Self-Destruction. Cambridge: Cambridge University Press.

Wright, C., Nyberg, D., De Cock, C. and Whiteman, G. (2013) 'Future Imaginings: Organizing in Response to Climate Change', Organization, 20(5): 647-58.

Wright, C., Nyberg, D., Rickards, L. and Freund, J. (2018) 'Organizing in the Anthropocene', Organization, 25(4): 455-71.

Yusoff, K., Grosz, E., Clark, N., Saldanha, A. and Nash, C. (2012) 'Geopower: A Panel on Elizabeth Grosz's Chaos, Territory, Art: Deleuze and the Framing of the Earth', Environment and Planning D: Society and Space, 30(6): 971-88. 